\title{
Structural Engineering International
}

\section{Eminent Structural Engineer: David P. Billington (1927-2018). Inspiring Generations Through the Integration of Engineering and Art}

\section{Professor Ignacio Payá-Zaforteza \& Professor Maria E. Moreyra Garlock}

To cite this article: Professor Ignacio Payá-Zaforteza \& Professor Maria E. Moreyra Garlock (2019) Eminent Structural Engineer: David P. Billington (1927-2018). Inspiring Generations Through the Integration of Engineering and Art, Structural Engineering International, 29:1, 175-178, DOI: $10.1080 / 10168664.2018 .1528851$

To link to this article: https://doi.org/10.1080/10168664.2018.1528851

曲 Published online: 13 Nov 2018.

Submit your article to this journal $\widetilde{ }$

Џ Article views: 78

Q View related articles ¿ત

View Crossmark data $[\pi$ 


\section{Eminent Structural Engineer: David P. Billington (1927-2018). Inspiring Generations Through the Integration of Engineering and Art}

Ignacio Payá-Zaforteza (D), Professor, Instituto de Ciencia y Tecnología del Hormigón (ICITECH), Universitat Politècnica de València, Valencia, Spain.; Maria E. Moreyra Garlock (D), Professor, Civil and Environmental Engineering, Princeton University, Princeton, NJ,

USA. Contact igpaza@cst.upv.es.

DOI: $10.1080 / 10168664.2018 .1528851$

\section{Partial CV}

- 1927 - Born June 1, Bryn Mawr, PA

- 1950 - Princeton University, BSE

- 1951 - Married Phyllis Bergquist, with whom he had six children

- 1950-1952 - Fulbright Fellowship, Leuven, Belgium, to study post-war innovations in bridge construction, structural design theory and prestressed concrete

- 1952-1960 - Structural Designer, Roberts \& Schaefer Co., New York, for bridges and buildings including aircraft hangers, piers, thin-shell tanks and rocket-launch facilities

- 1960-1964 - Associate Professor, Princeton University

- 1964-2010 - Professor, Princeton University

- 1965 - publishes first Edition, ThinShell Concrete Structures, 2nd Ed., 1982.

- 1979 - publishes Robert Maillart's Bridges, Princeton University Press, (Paperback, 1985) (Dexter Prize, 1979)

- 1973-1979 - Chairman, ACI-ASCE Joint Committee on Concrete Shell Design \& Construction

- 1974 - Introduced "Structures and the Urban Environment" course at Princeton University

- 1983 - publishes The Tower and the Bridge: The New Art of Structural Engineering, Basic Books, 1983 (Paperback, Princeton University Press, 1985)

- 1985 - Introduced first version of "Engineering in the Modern World" course at Princeton University

- 1990-2008 - Director, Princeton Program on Architecture and Engineering

- 1996-2010 - Gordon Y. S. Wu Professor of Engineering

- 1996 - publishes The Innovators: The Engineering Pioneers Who Made America Modern, John Wiley \& Sons

- 1986 - Elected Member, National Academy of Engineering
- 1990 - Honorary Doctor of Humane Letters, Union College

- 1991 - Honorary Doctor of Science, Grinnell College

- 1996 - Princeton University President's Award for Distinguished Teaching.

- 1998 - Election as a Fellow of the American Academy of Arts \& Sciences

- 1999 - Named one of five top educators in Civil Engineering since 1874 by the Engineering News Record

- 2003 - National Science Foundation Director's Distinguished Teaching Scholar Award

- 2015 - Honorary Doctor of Science, Princeton University

- 2018 - Dies March 25

\section{Introduction}

With the death of David P. Billington (Fig. 1) on 25 March 2018 at the age of 90 , the world lost one of its most inspiring, passionate and innovative civil engineering professors. Billington, who taught and researched at Princeton University in the US for more than 50 years, made several important contributions to the engineering profession. First of all, he demonstrated that structural engineering is a creative discipline, which as its best defines a new form of art that he named structural art. He also humanized engineering by showing the vision and importance of specific engineers who created elegant structures within the constraints of economy and efficiency, and who transformed society through other major engineering innovations such as the steamboat and the microchip. Billington's scholarship on thin shell structures defined standards and design approaches; and finally, through his books, papers, art exhibitions and lectures he inspired all kinds of people-engineers, students and general public- and contributed to create a better awareness of the importance of engineering.

This paper provides a brief background of Billington's life and experiences, examines his main contributions and explains his legacy. The article is based on the authors' personal experience, an interview conducted by the authors in 2010, and another interview ${ }^{1}$ conducted by Thomas Swift in 2012.

\section{Early years}

David P. Billington was born on 1 June 1927 in Bryn Mawr, PA, USA. He began his studies at Princeton University in 1946 where he took a program called "Basic Engineering" which contained specially designed courses on electrical, mechanical, chemical and aerospace engineering but no course on civil engineering. The program had far more electives than any other engineering program which was very appealing for Billington, who could then take courses on music, literature and art. This background in the humanities would be an important asset later on. After finishing his studies at Princeton, he applied for a Fulbright scholarship. The grant enabled him to spend two years in Belgium to study civil engineering during the first year and then prestressed concrete and his proposal was inspired by the Walnut Lane Memorial Bridge, the first prestressed concrete bridge built in the US. In Belgium, he worked with Prof. Gustave Magnel, a major figure in the development of prestressed concrete. The Fulbright grant also enabled Billington to meet a young pianist called Phyllis Berquist, who became his wife and principal source of support.

Back in the US, Billington started to work for Roberts \& Schaefer at their New York City office where he was involved in the design of thin shell structures and piers among other 

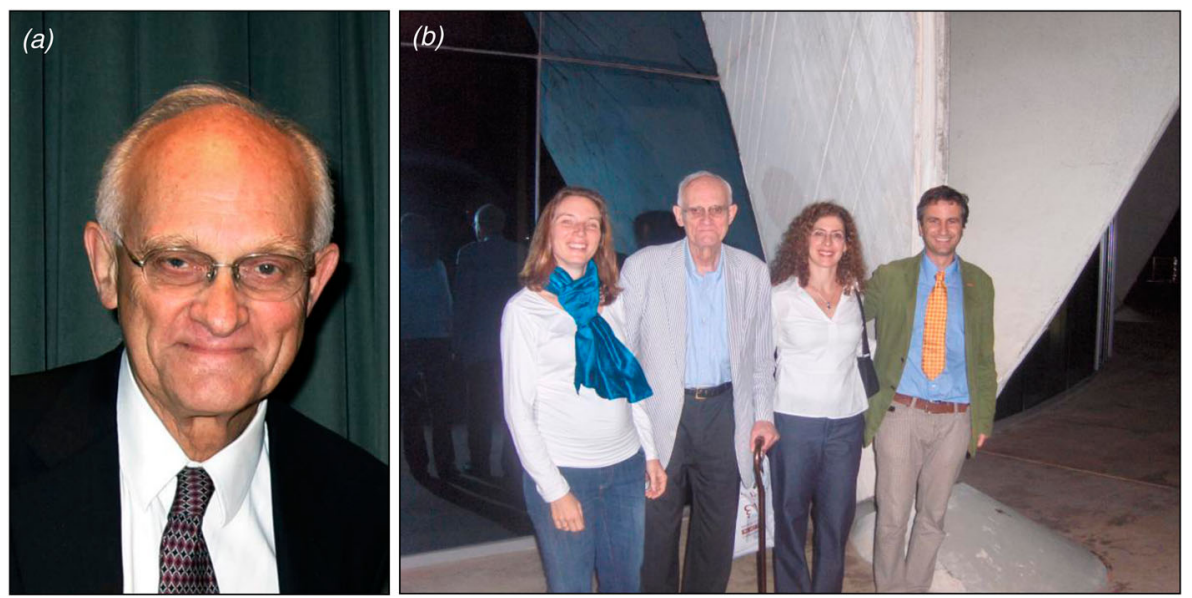

Fig. 1: (a) David P. Billington (1927-2018), photo by Rene Motro. (b) At the IASS Conference in Valencia 2009, shown second from left with some of those whom he has inspired and continue his legacy: Sigrid Adriaenssens (left), Maria Garlock (third from left) and Ignacio Paya Zaforteza (right). The group stands in front of the shell designed by Félix Candela for the Oceanogràfic park.

buildings. In 1958, he started to teach at Princeton University, first as a parttime lecturer teaching one course at night and, after 1960, full-time as an associate and then full professor. Near the beginning of his academic career, he taught a structural engineering class to students of architecture, who asked him why could not structural engineering be studied by looking at beautiful things. The students also gave him a copy of S. Giedion's book "Space, Time and Architecture"2 and pointed to the big chapter on Robert Maillart's bridges. Billington did not know anything about this Swiss engineer at that time, but he found the idea of teaching based on beautiful structural
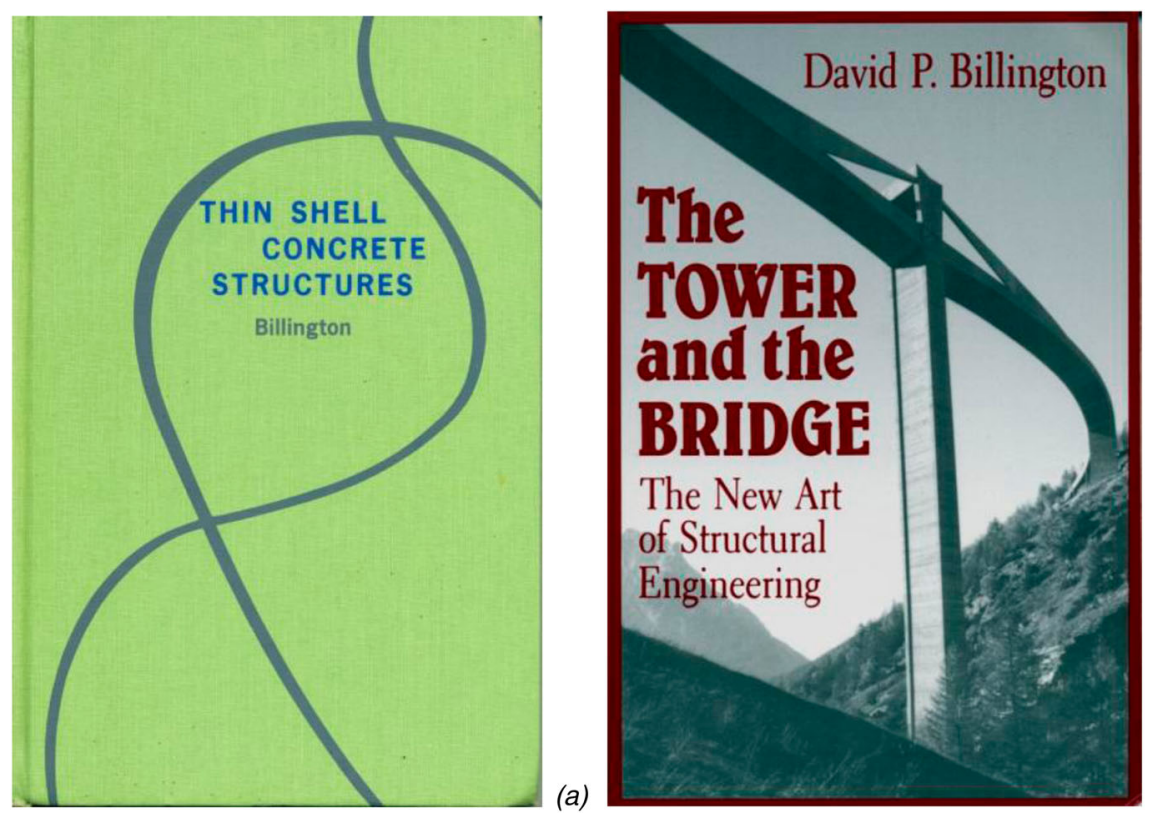

\section{Scholarship on Thin Shell Concrete Structures}

Billington did not have a $\mathrm{PhD}$ when he started at Princeton in 1960. He therefore considered his first book, Thin Shell Concrete Structures ${ }^{3}$ (Fig. 2a), pub-

lished in 1965 , equivalent to a doctoral

(a)

engineering examples very interesting This simple event launched Billington on a new course of scholarship that define a whole new field-Strucknown as the expert on thin shell concrete structures; but soon this expertise would be joined by his unique scholarship on the history of engineering.

Fig. 2: Seminal books written by David P. Billington thesis. The book is full of partial differential equations solving equilibrium for various thin shell forms-with and without bending stresses. He became an expert in thin-shell structures, which he reflects was important for being in academia - being able to write papers, consult, and "do all the things that you are supposed to do." The book, his scholarship, his work as a consultant and his leadership as the Chairman of ACI-ASCE Joint Committee on Concrete Shell Design \& Construction helped define standards and means for designing thin shell structures all around the world. However, while the book demonstrated his superior capabilities in applying high-order mathematics to analyze structures, he "really wasn't interested in (...) all this mathematics ... a strange situation to be in."1 His interests started to turn to the history of engineering, and when the second edition came out in 1982, the book included many examples of built structures. For example, the first chapter described thin shells from a historical perspective, and the last chapter presented the ideas of structural art as applied to roof shells. In other words, the second edition integrated the scholarship that he had begun on historical studies of structures and engineering. Billington felt the "tension" (pressure) of academia to continue his scholarship on thin shell structures, which had "lots of mathematics." He was either told, or it was implied to him, that this path " ... would be the way to gain more and more prestige ..." 1 To be distracted by scholarship based on historical studies of engineering went against the current of academic advice-and it took courage to embark on this new road.

\section{Scholarship and Teaching of "Structural Art"}

As discussed previously, Robert Maillart was the beginning of Billington's scholarship on the history of engineering. Following his experience teaching the students of architecture, Billington and his colleague Robert Mark, a professor of Architecture at Princeton began to analyze the humanistic side of engineering. Mark focused on the analysis of gothic cathedrals using photoelasticity. Billington, on the other hand, became very interested on Maillart and decided to organize in 1972 a conference at Princeton on the occasion of the hundredth anniversary of his birth. Three of the people 
who gave talks at that conference were Christian Menn, a Swiss engineer who continued the innovation in bridge design begun by Maillart; Felix Candela, the Spanish-born designer of thin shells in Mexico; and Fazlur Khan designer of tall buildings in the United States, who was born in Bangladesh. The conference was crucial as it gave Billington the idea for a new Princeton course, which would focus on a tradition of engineers having Maillart as a cornerstone and formed also by other individual people who were innovators in structural engineering.

Two years later the course "Structures in the Urban Environment" was taught for the first time. It has been taught continuously since then (now taught by the second author) and it remains now, as it was then, one of the most popular courses at Princeton. "Structures and the Urban Environment" traces the development of outstanding structures that arose with the industrial revolution and the introduction of new materials - industrialized iron, then structural steel, then reinforced concrete and finally prestressed concrete. The course includes detailed studies of works such as Maillart's Salginatobel Bridge (1930) in Switzerland, Khan's John Hancock Tower (1970) and Candela's Restaurant Los Manantiales (1958) in Xochimilco, Mexico. These are just some examples but the course highlights almost twodozen engineers. In each case, a brilliant engineer was responsible for the formand these forms illustrate engineering principles (e.g. the gravity-loaded arch, the wind-loaded cantilever, and the gravity-loaded thin shell). Each designer sought to integrate elegance and efficiency rather than superimpose one on the other. That is the concept of the new art form that Billington defined, structural art, which is measured by efficiency, economy and elegance. The case study examples illustrate how the best technical design leaves room for ethical and aesthetic choice. Thus, the creativity of the engineer is emphasized along with the technical content.

This course is based on Billington's scholarship of "structural artists" and their most important works. Such scholarship resulted in several books on Maillart $^{4-6}$, a book ${ }^{7}$ on the Swiss Engineers (Maillart, Menn, Heinz Isler and Othmar Ammann) and their teachers (Wilhelm Ritter and Pierre Lardy), and a book on Candela ${ }^{8}$ coauthored by the second author of this paper. His seminal book, The Tower and the Bridge ${ }^{7}$, published in 1983 (Fig. 2b), summarizes this scholarship and forms the foundation for the course. The book has been translated into Japanese, Spanish and German and is a classic in the literature on the philosophy of structures. The engineers and works described in the book together with the main developments in the analysis of structures have been compiled by the first author of this paper and summarized in a Structural Art timeline ${ }^{10}$ available open access. As a teacher, Billington believed that communicating frequently with practitioners was an important aspect of his teaching in structural engineering and an essential part of his scholarship so he kept in close contact with engineers such as C. Menn (Fig. 3), H. Isler and J. Schlaich.

\section{Scholarship on the History of Modern Engineering}

In 1982, the Introductory Engineering course that Princeton University had devised for their students did not go well and Billington, who had been successfully teaching "Structures in the Urban Environment", was asked to devise a course in its place. The new course began in 1985 as "Structures and Machines" - it only had the civil and mechanical engineering disciplines in it at the time-but he soon added electrical and chemical engineering components (networks and processes). Michael Littman, Professor of Mechanical Engineering, started to collaborate with Billington on the course in 1990 by teaching a seminar and together they transformed it by adding a lab (Fig. 4). The course was renamed "Engineering in the Modern World" and co-taught with Professor Littman, who continues teaching it to this day.

The course "Engineering in the Modern World" centers on the transformation of American society by engineering through studies of the great innovations of the nineteenth and twentieth centuries in the main branches of engineering (e.g. the steam engine and railway, the telegraph, Edison's power network, the steel bridge, the refining of oil, the automobile and the airplane,

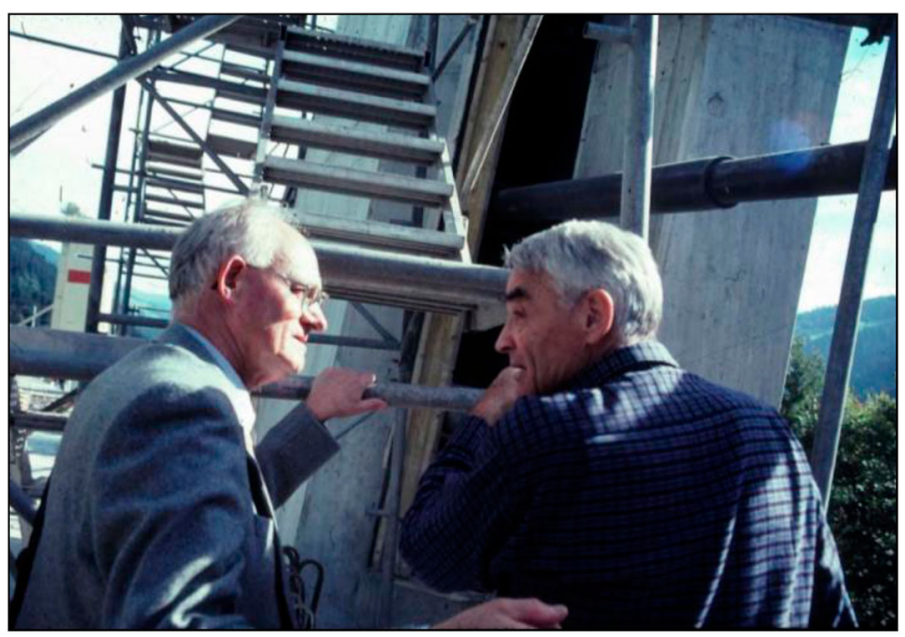

Fig. 3: David P. Billington (left) and Christian Menn (right) at the construction of the Sunniberg Bridge.

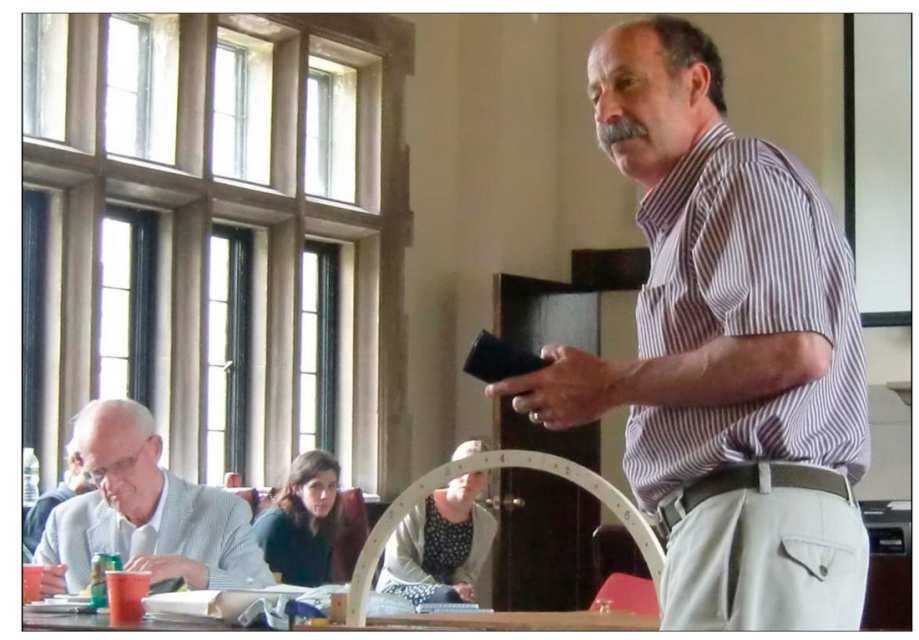

Fig. 4: Michael Littman (front) and David P. Billington (left) during a Princeton civil engineering alumni meeting held in June 2009. Prof. Littman is explaining one of the components (an arch) of the lab used in the course "Engineering in the Modern World". 
electronics from the radio to the microchip). The course explains the technical ideas of well-known engineers, such as the Wright Brothers, and less well-known engineers such as the inventors of the microchip, Jack St. Clair Kilby and Robert Noyce. The course integrates engineering into American history and shows how the key innovations of modern life build on past innovations and do not simply appear in isolated succession.

\section{Engineering Education for General Public}

These two courses "Structures in the Urban Environment" and "Engineering in the Modern World" are taught to both engineering and non-engineering students. Billington believed that key to teaching these introductory engineering courses to both engineering and non-engineering students was to show how engineering integrated the study of nature, society and art, the traditional concerns of the liberal arts. Through examples, he showed how the best engineers make design choices that work within nature and its laws, are economical and socially useful, and within these constraints express the humanistic and aesthetic vision of the individual engineer. He believed that showing this interconnections between liberal arts and engineering is a crucial step in the education of all students because it makes them aware, early in their careers, of how engineering ideas and works require an understanding of science, politics and the personality of individual engineers.

In addition to the two courses and books - all designed for a general audience-Billington also curated several exhibitions. In fact, the museum exhibitions at Princeton began with the conference in 1972. Billington believed that if he were to dive into this field of art and aesthetics he needed a relationship with the art museum. $\mathrm{He}$ went on to curate seven other exhibitions, most of which traveled to other museums and even abroad. His last exhibition on Felix Candela was cocurated by the second author.

\section{Legacy and Source of Inspiration}

Billington's contributions earned him many awards and honors. Among them, a Doctor of Science honorary degree from Princeton University received in 2015. The degree citation, which was written by the second author and slightly edited by the University, reads as follows: "An epic scholar and legendary teacher, he inspired students, colleagues and designers to integrate the discipline of engineering with the play of art. From Fulton's steamboat to Maillart's bridges, he introduced us to the engineering pioneers who revolutionized the world and opened our eyes to the creativity of engineering at its best. 'Structural art' is his vocabulary for bridges, towers, and vaults that embrace efficiency through form, economy through construction, and elegance through structural expression. His legacy is the generations of students whose lives were formed and shaped by exposure to his love for and deep appreciation of engineering as art."

The word "students" should be understood in a broad sense, since thanks to his books and exhibitions, Billington inspired people from all around the world. One of such people was the first author of this paper, who discovered by accident the book "The Tower and the Bridge" ${ }^{\prime \prime}$ in 2006. Its reading provoked a completely new view about engineering based on the way structures relate to architecture, politics and society. Later on (20092010), the first author had a direct contact with Billington during a long stay at Princeton. There he discovered that Billington was much more than a big name and an outstanding scholar and teacher, he was a true "Maestro", a very special and endearing person with an acute sense of humor.

When the second author was an assistant professor, Billington suggested that they embark upon a study of Candela, complete with a book and museum exhibition. Her colleagues were concerned - this is not a wise way for an assistant professor to spend her time. The risk paid huge rewards, not the least of them being the experience of being mentored by Billington. Taking risks, being courageous, and believing in herself are professional values that Billington taught her.

On the last day of the "Structures in the Urban Environment" class of 2018, the second author asked the students to write on a card a response to "What will you never forget about this class?" Over 100 students responded enthusiastically with a range of subjects (the story of the Roebling family and the Brooklyn Bridge was the most popular response). Two responses in particular relate to the significant and intangible influence of Billington: "Prof. Garlock's passion and sincerity" and her "infectious enthusiasm." Such is the legacy of Billington's teaching that is memorialized at Princeton and elsewhere: His enthusiasm for teaching and structural art was "infectious", and his "passion" was sincere. It is the authors' wish that Billington's enthusiasm, passion and sincerity for teaching and for structural engineering will continue to inspire generations to come.

\section{ORCID}

Ignacio Payá-Zaforteza (ㄱ) http://orcid. org/0000-0002-3995-8772

Maria E. Moreyra Garlock (1) http:// orcid.org/0000-0002-6465-9504

\section{References}

[1] Swift T. Oral History Project. Interview with David P. Billington April 26. Seeley G. Mudd Manuscript Library. 2012. .https://webspace. princeton.edu/users/mudd/Accessions/ UnivArchives/AC259/AC259_billington.pdf Accessed online July 3, 2018

[2] Giedion S. Space, Time and archItecture. The Growth of a New Tradition. Harvard University Press: Cambridge, MA, USA, 1943.

[3] Billington DP. Thin Shell Concrete Structures. McGraw-Hill Book Co., New York, USA, 1965.

[4] Billington DP. Robert Maillart's Bridges. Princeton University Press, 1979.

[5] Billington DP. Robert Maillart and the Art of Reinforced Concrete. Architectural History Foundation and Artemis (Zurich). Bilingual Publication, MIT Press, 1990.

[6] Billington DP. Robert Maillart: Builder, Designer, Artist, A Biography. Cambridge Univ. Press, 1997.

[7] Billington DP. The Art of Structural Design: A Swiss Legacy. Yale University Press, Princeton University Art Museum (Paperback), 2003.

[8] Garlock M, Billington DP. Felix Candela: Engineer, Builder and Structural Artist. Princeton University Art Museum and Yale University Press, 2008.

[9] Billington DP. The Tower and the Bridge. The New Art of Structural Engineering. New York: Basic Books, 1983.

[10] Payá Zaforteza I. Structural Art Timeline. Cinter, Divulgación Técnica 2013. Available for download from http://www.cinter.es/ latorreyelpuente.htm. Accessed online July 5, 2018. 